\section{SOME RECENT BIRD RECORDS FOR PRAIRIE CANADA}

\section{by B. J. Rose, Bismarck, North Dakota}

Since May 31, 1961, I have made frequent trips into the prairie and aspen grove regions of Manitoba, Saskatchewan, and Alberta. These journeys were made while studying methods of preserving Canadian wetlands and establishing a priority rating system for these wetlands for the National Wildlife Federation under a grant from the Max C. Fleischmann Foundation of Nevada. A few observations made on these trips seem worth noting.

Black-crowned Night Heron (Nycticorax nycticorax) - A single adult was seen on a creek a few miles west of Seven Persons, Alberta, on June 18, 1964.

Black Duck (Anas rubripes) - A single adult was noted on a small creek four and seven-tenths miles east of Kylemore, Saskatchewan, on June 5, 1965.

Cinammon Teal (Anas cyanoptera) - A pair was observed about five miles north of Czar, Alberta, on June 25,1961 . A lone male was seen about four miles west of Stewart Valley, Saskatchewan on June 7, 1965.

Hooded M e rganser (Lophodytes cucullatus) - A single female or immature male was seen on the Frenchman River at Val Marie, Saskatchewan, June 7, 1961; a single hen or immature male was observed and photographed on a small impoundment approximately eight miles north of Swift Current, Saskatchewan on June 7, 1965.

Dunlin (Erolia alpina) - A flock of 21 was observed during heavy rainfall at a small pothole about 10 miles north of Killarney, Manitoba on May $21,1963$.

Lazuli Bunting (Passerina amoena) - A female was found dead on the highway about one mile east of Irma, Alberta, on June 20, 1964. The specimen was given to the University of Saskatchewan, Saskatoon Campus.
Smith's Longspur (Calcarius pictus) - A single male was observed with a flock of Lapland Longspurs and Snow Buntings about seven miles southwest of Kinistino, Saskatchewan on April 23, 1963.

\section{SECOND LAZULI BUNTING NESTING RECORD AT MOOSE JAW}

\author{
by Rosalind Taylor, Moose Jaw
}

On June 7, 1965, I saw a male Lazuli Bunting (Passerina amoena) perched on top of a telephone pole just a few yards from our door. This is the same location in which I observed one last year on July 9 (reported in September, 1964 Blue Jay), but this time I had the good fortune of observing him many times, for he stayed practically all summer. My last observation was the morning of August 5. I also became familiar with the song of the Lazuli Bunting, since this telephone pole and a neighbor's TV aerial proved to be two of his favorite singing posts. I heard him sing most frequently from July 18 to 22 , the peak day being the 19th. In addition to singing at intervals during the day, he sang several evenings as late as nine o'clock. One evening we were thrilled to have this jewellike bird fly right across our laps while we were sitting on the porch. His destination was the peonies nearby. We often noticed him around the peonies in the neighbourhood.

Among those who saw the Lazuli Bunting were Mr. John Nelson, president of the Moose Jaw Natural History Society, Christopher Lacny, a junior member who first alerted us to the bird's presence in the neighborhood, and Dr. A. J. Beddie who not only saw the male, but also the female and several young. The nest, he thinks, was in his yard. This is the second breeding record for Moose Jaw. Eight years ago a pair nested in Mrs. R. J. Dunn's garden (Blue Jay $15: 147$ ). We hope this beautiful bird will favor us with his presence more frequently in the future. 